\title{
Development and characterization of novel microsatellite markers in the rock bream fish Oplegnathus fasciatus
}

\author{
X.X. Sun ${ }^{1,2}$, D.D. Xu' ${ }^{2}$, B. Lou ${ }^{2}$, S.L. Li ${ }^{1,2}$, W. Zhan ${ }^{2}$, Y.R. Zhang ${ }^{2}$ and J. Xin ${ }^{2}$ \\ ${ }^{1}$ Zhejiang Ocean University, College of Marine Science, Zhoushan, \\ Zhejiang Province, China \\ ${ }^{2}$ Marine Fishery Institute of Zhejiang Province, \\ Key Lab of Mariculture and Enhancement of Zhejiang Province, \\ Zhoushan, Zhejiang Province, China \\ Corresponding author: D.D. Xu \\ E-mail: xudong0580@163.com
}

Genet. Mol. Res. 12 (4): 6462-6465 (2013)

Received March 18, 2013

Accepted July 4, 2013

Published December 10, 2013

DOI http://dx.doi.org/10.4238/2013.December.10.7

\begin{abstract}
The rock bream fish Oplegnathus fasciatus is one of the most popular aquaculture species in China. In the present study, 15 novel polymorphic microsatellite loci were isolated and characterized from a wild population of $O$. fasciatus from the Zhoushan coast of China. The number of alleles per polymorphic locus ranged from 4 to 9 in a sample of 30 individuals. Observed and expected heterozygosities per locus varied from 0.267 to 0.767 and from 0.395 to 0.859 , respectively. Eleven of the 15 microsatellite loci conformed to Hardy-Weinberg equilibrium. No significant linkage disequilibrium between pairs of loci was detected. The present microsatellite markers could provide a useful tool for the genetic analyses of $O$. fasciatus.
\end{abstract}

Key words: Oplegnathus fasciatus; Microsatellite; Polymorphism 


\section{INTRODUCTION}

The rock bream Oplegnathus fasciatus is a subtropical and carnivorous fish species that belongs to the Oplegnathidae family (Meng et al., 1995). This species is an economically important marine fish in East Asia. It has recently been considered as a potential species for commercial aquaculture and stock enhancement. For the purpose of fishery management and aquaculture development programs in $O$. fasciatus, studies on the genetic structure of $O$. fasciatus are urgently required. Microsatellite DNA loci are the most popular and powerful molecular markers for genetic analysis (Liu and Cordes, 2004). However, only 66 microsatellite sequences have been published for $O$. fasciatus in GenBank to date (An et al., 2006; Xu et al., 2009). More microsatellite markers are required for genetic analyses in O. fasciatus. In the present study, we report an additional 15 microsatellite markers for $O$. fasciatus.

\section{MATERIAL AND METHODS}

Thirty $O$. fasciatus individuals were collected from the coast of Zhoushan Island $\left(122^{\circ} 30^{\prime} \mathrm{N}, 30^{\circ} 08^{\prime} \mathrm{E}\right)$. Microsatellite loci were isolated and cloned according to the protocol described by Yue et al. (2000). Genomic DNA was extracted from fin clips of two individuals (one male and one female) using a method described previously (Yue and Orban, 2005). The genomic DNA extracted was then digested with $R s a$ I and DNA fragments of 250-1000 bps were selected on agarose gel and recovered using a DNA purification kit (Tiangen, Beijing). Fragments were then ligated with 20 pmol 21- and 25-mer oligo adaptors (Fischer and Bachmann, 1998). Using the linker sequences as specific primers, the ligation products were amplified and the amplified products were hybridized to biotinylated probes (CA) ${ }_{10}$ and streptavidin-coated magnetic beads (Dynal). Magnetic beads captured DNA containing microsatellites were eluted. The eluted fragments were amplified using 21-mer as primers, ligated to a pGEM-T-vector (Promega, Shanghai), and then transformed into XL-blue 1 competent cells (Stratagene). Colony polymerase chain reaction (PCR) products were tested in an ABI3100 sequencer (Applied Biosystems). Primers were designed for 15 microsatellites in the regions flanking repeats using the Primer 3.0 software (Rozen and Skaletsky, 2000).

All of the 15 pairs of primers were examined in a wild population of 30 individuals collected from the coastal water of Zhoushan. PCR amplification was performed in a $25-\mu \mathrm{L}$ reaction mixture including $10 \mathrm{pmol}$ of each primer set, $100 \mu \mathrm{M}$ dNTPs, $10 \mathrm{mM}$ Tris-HCl, $\mathrm{pH}$ $8.3,50 \mathrm{mM} \mathrm{KCl}, 1.5 \mathrm{mM} \mathrm{MgCl}$, $1 \mathrm{U}$ Taq polymerases (TaKaRa), and $40 \mathrm{ng}$ template DNA. The reactions were carried out using the following conditions separately: $5 \mathrm{~min}$ at $94^{\circ} \mathrm{C} ; 35$ cycles of $30 \mathrm{~s}$ at $94^{\circ} \mathrm{C}, 45 \mathrm{~s}$ at annealing temperature, and $1 \mathrm{~min}$ at $72^{\circ} \mathrm{C}$, and a final extension step of $7 \mathrm{~min}$ at $72^{\circ} \mathrm{C}$. Following amplification, PCR products were mixed with $5 \mu \mathrm{L}$ of sequencing dye and heated for $5 \mathrm{~min}$ at $95^{\circ} \mathrm{C}$. Amplified products were separated on $6 \%$ denaturing polyacrylamide gels and visualized by silver staining. A 10-bp DNA ladder (Fermentas) was used to identify the alleles. The number of alleles, observed heterozygosity $\left(H_{\mathrm{O}}\right)$, and expected heterozygosity $\left(H_{\mathrm{E}}\right)$ were calculated using the POPGENE version 3.2 software (Raymond and Rousset, 1995). Conformance of genotypic proportions to Hardy-Weinberg equilibrium was tested using exact tests in the ARLEQUIN 3.01 software (Excoffier et al., 2005). Probability values were determined based on 10,000 dememorizations of 1000 batches with 10,000 iterations per batch. 


\section{RESULTS AND DISCUSSION}

Fifteen polymorphic microsatellite markers were successfully screened in $O$. fasciatus (Table 1). The microsatellite data were analyzed using POPGENE version 3.2 (Raymond and Rousset, 1995), which indicated that the number of alleles ranged from four to nine, with an average of 5.93 alleles per locus. The observed and expected heterozygosity at the population level varied from 0.267 to 0.767 and from 0.395 to 0.859 , respectively. The average $H_{\mathrm{O}}$ and $H_{\mathrm{E}}$ was 0.516 and 0.724 , respectively. Four microsatellite loci, namely Opfa01, Opfa03, Opfa09, and Opfa11, deviated significantly from the Hardy-Weinberg equilibrium $(\mathrm{P}<0.01)$. No evidence of linkage disequilibrium was observed in any pair of loci. In summary, these new informative microsatellite markers will be useful in genetic studies of $O$. fasciatus, and will thereby help to improve natural resource protection and genetic breeding studies.

\begin{tabular}{|c|c|c|c|c|c|c|c|c|}
\hline Locus & Repeat motif & Primer sequence $\left(5^{\prime}-3^{\prime}\right)$ & $\mathrm{Ta}\left({ }^{\circ} \mathrm{C}\right)$ & $N_{\mathrm{A}}$ & Allele-size range & $H_{\mathrm{o}}$ & $H_{\mathrm{E}}$ & $P_{\mathrm{HW}}$ \\
\hline Opfa01 & $(\mathrm{GT})_{11}(\mathrm{GT})_{5}$ & $\begin{array}{l}\text { F: TTGTCTGACTGTCTGTGCTTTTGTT } \\
\text { R: GTTGACTAATGCGATGCTGGTTC }\end{array}$ & 54 & 7 & $236-260$ & 0.333 & 0.841 & 0.000 \\
\hline Opfa02 & $(\mathrm{CA})_{13}$ & $\begin{array}{l}\text { F: TGTTTGAGTGATGTTGTGCGTC } \\
\text { R: GCTCCTCCAAGGGCTTTAGAT }\end{array}$ & 54 & 4 & $101-251$ & 0.267 & 0.395 & 0.215 \\
\hline Opfa03 & $(\mathrm{TG})_{8}(\mathrm{GTGC})_{10}$ & $\begin{array}{l}\text { F: TGATGTTGTCTGGTCCTCTTCGT } \\
\text { R: GGGTCCTGACTCACTCTACACTGG }\end{array}$ & 55 & 5 & $157-215$ & 0.567 & 0.781 & 0.000 \\
\hline Opfa04 & $(\mathrm{AC})_{14}$ & $\begin{array}{l}\text { F: GCAGACACTTCTTCCCACAC } \\
\text { R: GCGCACACTCACACGCCTT }\end{array}$ & 55 & 5 & $228-306$ & 0.467 & 0.680 & 0.384 \\
\hline Opfa05 & $(\mathrm{AC})_{16}$ & $\begin{array}{l}\text { F: AGCGGAGTCCACACAGGT } \\
\text { R: TTGGGGGGACACATAGTTT }\end{array}$ & 51 & 5 & $201-219$ & 0.767 & 0.782 & 0.017 \\
\hline Opfa06 & $(\mathrm{CA})_{7}(\mathrm{AC})_{16}$ & $\begin{array}{l}\text { F: GTCCACCAAAAAATCCCATCT } \\
\text { R: TGTTCTGTGTGCGACTCCTAAA }\end{array}$ & 51 & 6 & $180-217$ & 0.433 & 0.664 & 0.117 \\
\hline Opfa07 & $(\mathrm{CA})_{17}$ & $\begin{array}{l}\text { F: TGAAGCCCAGGAGGCAACAC } \\
\text { R: GCTAACAAAACCGCCGCAGT }\end{array}$ & 55 & 6 & $471-621$ & 0.433 & 0.723 & 0.059 \\
\hline Opfa08 & $(\mathrm{CA})_{9}(\mathrm{AC})_{5}$ & $\begin{array}{l}\text { F: GAGAGGAGAAGTGAAATCTGAAT } \\
\text { R: GCGTCTGCCTACCTAAAGC }\end{array}$ & 52 & 4 & $184-203$ & 0.633 & 0.623 & 0.068 \\
\hline Opfa09 & $\begin{array}{l}(\mathrm{GT})_{10}(\mathrm{GA})_{5} \\
(\mathrm{AG})_{6}(\mathrm{GA})_{17}\end{array}$ & $\begin{array}{l}\text { F: AACACAGGGAACGGGCAG } \\
\text { R: TTAGTCAGAGAAGAGGCAGAGAAAT }\end{array}$ & 54 & 7 & $275-457$ & 0.300 & 0.844 & 0.000 \\
\hline Opfa10 & $(\mathrm{GA})_{17}$ & $\begin{array}{l}\text { F: ACAACGCTGGTAAATGGCTC } \\
\text { R: TAAAACGATGGTGAAAGACGC }\end{array}$ & 51 & 5 & $457-707$ & 0.667 & 0.662 & 0.083 \\
\hline Opfa11 & $(\mathrm{AC})_{24}(\mathrm{AC})_{13}$ & $\begin{array}{l}\text { F: TTGTTTACTGATTTTGTCTGTGGTTGT } \\
\text { R: TCACGCACACACGCAGACTAAT }\end{array}$ & 53 & 6 & $625-779$ & 0.467 & 0.759 & 0.006 \\
\hline Opfa12 & $\left.(\mathrm{CT})_{19} \mathrm{TC}\right)_{11}$ & $\begin{array}{l}\text { F: AGTAAGGACAAACTCTGAATAGCA } \\
\text { R: AGCAACAGCACAGTGGTAGC }\end{array}$ & 52 & 6 & $445-514$ & 0.633 & 0.786 & 0.089 \\
\hline Opfa13 & $\begin{array}{l}(\mathrm{TG})_{13}(\mathrm{GA})_{15} \\
(\mathrm{AG})_{5}\end{array}$ & $\begin{array}{l}\text { F: CCACCTCACTGATTCCTACAT } \\
\text { R: TCTCTCTTTTTCCCTCCCTA }\end{array}$ & 51 & 9 & $455-549$ & 0.700 & 0.859 & 0.075 \\
\hline Opfa14 & $(\mathrm{GA})_{15}(\mathrm{AG})_{5}$ & $\begin{array}{l}\text { F: CAGCCCACCTCACTGATTCCTA } \\
\text { R: CCTATTTGTCTGTGCTTCTTCGG }\end{array}$ & 55 & 9 & $480-549$ & 0.700 & 0.843 & 0.095 \\
\hline Opfa15 & $(\mathrm{TG})_{13}(\mathrm{GT})_{5}$ & $\begin{array}{l}\text { F: CGATGGCAAGATACAGCACG } \\
\text { R: AACACAGCGGAGACCTGATGA }\end{array}$ & 55 & 5 & $523-655$ & 0.367 & 0.615 & 0.011 \\
\hline
\end{tabular}

Ta = annealing temperature, $N_{\mathrm{A}}=$ number of alleles, $H_{\mathrm{O}}=$ observed heterozygosity, $H_{\mathrm{E}}=$ expected heterozygosity, and $P_{\mathrm{HW}}=$ probability of departure from Hardy-Weinberg equilibrium.

\section{ACKNOWLEDGMENTS}

Research supported by grants from the National Natural Science Foundation of China (\#41106114), the National Science and Technology Pillar Program of China (\#2011BAD13B08), and the Project of Zhejiang Province of China (\#2010R50025; \#2010F20006). 


\section{REFERENCES}

An HS, Kim JW and Park JY (2006). Microsatellite DNA loci in the rock bream Oplegnathus fasciatus. Mol. Ecol. Notes 6: 44-46.

Excoffier L, Laval G and Schneider S (2005). Arlequin (version 3.0): an integrated software package for population genetics data analysis. Evol. Bioinform. Online 1: 47-50.

Fischer D and Bachmann K (1998). Microsatellite enrichment in organisms with large genomes (Allium cepa L.). Biotechniques 24: 796-800, 802.

Liu ZJ and Cordes JF (2004). DNA marker technologies and their applications in aquaculture genetics. Aquaculture 238: 1-37.

Meng QW, Su JX and Miao XZ (1995). Fish Taxonomy China Agriculture Press, Beijing.

Raymond M and Rousset F (1995). GENEPOP (version 3.2) population genetic software for exact tests and ecumenicism. J. Hered. 86: 248-249.

Rozen S and Skaletsky H (2000). Primer3 on the WWW for general users and for biologist programmers. Methods Mol. Biol. 132: 365-386.

$\mathrm{Xu}$ TJ, Shao CW, Liao XL, Ji XS, et al. (2009). Isolation and characterization of polymorphic microsatellite DNA markers in the rock bream (Oplegnathus fasciatus). Conserve Genet. 10: 527-529.

Yue GH and Orban L (2005). A simple and affordable method for high-throughput DNA extraction from animal tissues for polymerase chain reaction. Electrophoresis 26: 3081-3083.

Yue GH, Chen F and Orban L (2000). Rapid isolation and characterization of microsatellites from the genome of Asian arowana (Scleropages formosus, Osteoglossidae, Pisces). Mol. Ecol. 9: 1007-1009. 